\title{
Resistance to Early Mass Media
}

\begin{abstract}
Media resistance was shaped by industrialization and urbanization, and the debates over mass society and mass culture. The chapter reviews resistance to early mass media: print and books, serial fiction, cinema, radio and comics, and show how these media were seen to undermine morality, culture, enlightenment, democracy, community and health. The chapter discusses campaigns and protests against early mass media and shows that a common feature was a struggle for political and institutional control, prohibition or censorship.
\end{abstract}

Keywords Media history $\cdot$ Mass culture $\cdot$ Mass society $\cdot$ Censorship

\section{SMASH THE Vitascope!}

The first US exhibition of Thomas Edison's Vitascope, a Motion Picture projector, took place in 1896. Literary editor Herbert Stone protested:

I want to smash the Vitascope. The name of the thing is itself a horror. Its manifestations are worse (cited from French and Petley 2007, 8).

Throughout history there have been many strong exclamations as to what people would like to do to media, although calls for destruction

*is used throughout the book to indicate my translation.

(C) The Author(s) 2017 
waned as mass media proliferated. This chapter explores media resistance and scepticism in the early mass media era, showing how historical conditions from the beginning shaped both media and concerns about their negative impact. I begin with resistance to writing, print and books, before moving on to the mass media emerging in the wake of the industrial revolution: serial literature, cinema, radio and comics.

Resistance is directed at both new and old media, but in this chapter, the emphasis is on resistance when the media were new. The early phases of a medium's life fascinate scholars as well as history buffs; this is the era when fantasy and speculation contribute to how a new medium is understood (Natale and Balbi 2014, 208, see also Marvin 1988; Boddy 2004). New media are met with high expectations, but also with ambiguity, distrust and dystopic visions. In the early phase of a medium's life, warnings are issued about potentially destructive effects; in later phases these may be overtaken by explanatory narratives where social ills are explained by reference to ongoing media influence.

The historical sweep in this chapter cannot do justice to the twists and turns of each medium's early history, the purpose is instead to identify what was at stake for resisters: What were the social and political projects that were perceived to be most profoundly challenged by emerging media? I show how concerns for morality and culture were complemented with concerns for enlightenment, democracy and community, and how the media were often considered a threat to mental and physical health. In addition to perspectives and arguments, the chapter discusses actors and actions; what were the methods proposed and employed to limit, curtail and restrict? Important sites of struggle in this early phase were the legal and political domains, but also schools, libraries, churches, public areas and homes. Examples and cases are drawn from the UK, the US and Scandinavia, with scattered examples from elsewhere, but the purpose is not to do a stringent comparative analysis. Instead, the aim is to identify concerns and actions that became emblematic and representative in a Western context, and had impact across national and social boundaries.

In the chapter, I am indebted to existing media and cultural histories, as well as historically informed discussions of media theory (see, for example, Bastiansen and Dahl, 2003; Brantlinger 1983; Scannell 2007, Ytreberg 2008, Storey 2009; Fang 2015). In addition, the chapter draws on expressions of protest, criticism and scepticism in articles, books, political documents and other non-fiction material. 


\section{Writing, Print, Books: Early Expressions of Resistance}

Writers and commentators often date criticism of "new media" back to the ancients. According to Plato, Socrates opposed the teaching of writing. He disliked that text was mute and did not engage in dialogue, and warned that the alphabet and writing would create forgetfulness since people would no longer depend on memory (Plato around 370 BC, see also Fang 2015, 21). The position of Plato himself is also often cited; he advocated artistic censorship, believing that art should inspire "appropriate social attitudes and behaviour" (Solomon and Higgins $1996,54)$. From the beginning of philosophy, a key question has been how to live a virtuous life, and moral philosophy, as well as various religious denominations, has prescribed rules of good behaviour (Solomon and Higgins 1996; Brantlinger 1983). Perhaps the strongest argument against new media has been that they have not supported this moral endeavour, but instead embody characteristics that threaten to undermine what is virtuous and valuable.

It is always risky to take a contemporary phenomenon and draw historical lines back to a time when conditions were entirely different. In this book, the emphasis is on media developing from the nineteenth century, and I make no claims to present a full history of media resistance. However, some historical observations are interesting in a longue durée perspective - a perspective that emphasizes continuities in structures and mentalities (Braudel 1980). Particularly interesting are early reactions to writing, print and books.

The shift from oral to written culture in ancient history is the first of many shifts in media modes and functions. In the early modern period, the invention of printing as well as the arrival of paper in Europe prompted a new shift in communicative modes. Printed material became important for trade, the rise in colloquial speech and the spread of dissenting ideas (Barnouw 1966, 3). But printed material also challenged the King and the Church, and undermined the religious monopoly on knowledge. The Church's reaction to the invention of printing was dual; printed bibles made God's words accessible, but the technology of printing could also be used to distribute unauthorized material. Reactions were brutal: In the sixteenth century, the Catholic Church prohibited reading of heretical writings, offending books were consigned to public bonfires, and an Index was drawn up of prohibited books (Fang 2015, 46ff). In contrast, lists of "good" books became the basis for collections and later public libraries (Hertel 1986, 347-348). 
The duality in the Churches' reactions were mirrored by others' in the early modern era. In the essay What is Enlightenment, Kant (1997) encouraged fellow citizens to trust their own reasoning, and believers in enlightenment and universal education held high hopes for the revolutionary technology of print. But as mass distribution of printed material flourished, concern intensified about popular taste in content, and new lines were drawn between art and non-art, and between acceptable and non-acceptable genres (Newcomb 2002, 8). Each new genre was met with ambivalence; for example, when the novel became popular in England the eighteenth century, it was at first considered a "vulgar phenomenon" (Williams 1958, 306). In contrast, poetry, drama and the verse epic were seen as the ultimate literary genres (Öhman 2002, 10).

The immersion of readers in novel plots intensified concerns about copycat behaviour, a recurring theme in the history of media resistance. Would readers be able to distinguish between literary depictions and real life, or would they copy the behaviour of literary characters? A much discussed novel, which exemplifies the concerns raised by popular reading, was Goethe's The Sorrows of Young Werther [Die Leiden des jungen Werthers], a 1774 bestseller about a young man committing suicide when he is unable to marry the woman he loves. The novel had a huge impact and gave rise to intense discussion on the ethical problem of suicide and whether it was morally responsible to depict suicide in print. The Gentleman's Magazine for 1784 reported the unfortunate destiny of a Miss Glover who was found dead with a copy of "Werther" under the bed; the magazine blaming "the evil tendency of that pernicious work" (cited from Swales 1987, 94-95). In 1775 the Leipzig city council responded to a petition from the theological faculty and made it an offence, punishable by fine, to sell copies of the novel, remaining in force to 1825 (97).

The debates over early print media illuminate the use of metaphors in media scepticism and resistance; there is a rich tradition of rhetorical expressions characterizing media and use of media negatively and many predate the mass media era. Several are linked with disease; Krefting et al. (2014) show how the public sphere in the eighteenth century expanded despite warnings about "the writing epidemic"*. The Danish writer Ludwig Holberg was among the critics, he expressed strong concern for the contagious "writing diarrhoea" * that prevailed in his time and urged "charlatans" from all classes not to pick up the pen and let their thoughts out (9). In other words, the development of writing, reading and books was marked by enthusiasm, but also ambivalence, disillusionment and resistance. 


\section{Serial Fiction: Poisoning the Mind}

The period from 1850 to 1920 is described as the "the great technical revolution"* (Bastiansen and Dahl 2003, ch. 3). Universal education systems greatly extended literacy, and inventions in production and distribution technologies - printing presses and railway networks - made printed material widely available. Shorter working days, lamps and electricity allowed reading for leisure. The rise in advertising enabled new forms of financial support for popular media; Hilmes $(2007,20)$ describes "an explosion in numbers, forms and types of media" in the US between 1890 and 1920. Media went from being organs published by and for the elite, to be directed at people in general.

This was a great epoch of media resistance. Intellectuals and professionals had to come to terms with spectacular new forms of mass communication: based on not only the printed words but also electromagnetism, sound and images (Marvin 1988). To sceptics, popular media blossomed "like weeds on a hot day" (Hilmes 2007, 20).

The first genuinely popular genre was serialized fiction, emerging first in newspapers from the 1830. The stories drew inspiration from folk tales and oral culture; thrillers and mysteries, romance and historical epics, science fiction and horror could be found in the cheap volumes (Öhman 2002; Sutter 2003). Stories were sold for a dime in the US and a penny in the UKhence the terms "Dime novel" and the more deprecating "Penny dreadful." Cheap literature was also called "pulp fiction" because of the rough pulp paper. Serial fiction was from the beginning considered an outright threat to culture: it was formulaic, with no literary merit, poor writing style, plot and characterization (Bierbaum 1994, 95). The voluminous character of the series - often several thousand pages - was attributed to the fact that authors received payments per sheet and were writing purely for money (Öhman $2002,9)$. Since characters were to survive through a drawn-out narrative, the stories depended heavily on stereotypes. Ethnic stereotypes in popular fiction came "complete with predictable occupations and phonetically rendered dialects" (Bierbaum 1994, 95).

Popular fiction drew condemnations on moral grounds. The moral criticism continued to be based in the belief that literature should depict good behaviour and elevate individuals to a higher moral level (Drotner 1999, 603). In popular fiction, heroes were often lawless, such as pirates and highwaymen. Female characters were active and strong-willed, and sometimes lawless too, and it was commonplace to warn that popular 
literature would teach young people criminal behaviour (Sutter 2003, 166). The new genres were seen as particularly detrimental to the young, but women and working class men were also seen to be vulnerable to their influence (Öhman 2002, 12). Publishers were prosecuted; an extract from a criminal indictment for obscene libel in Britain stated that the defendant intended to "debauch, poison and infect the minds" of youth (cited from Lewis 2003, 145). Health threats were imminent; a US official report from 1876 referred to warnings from physicians that reading romantic literature would lead to disorders of the "nerve centres," which had "so alarmingly increased" (cited from Bierbaum 1994, 93).

The resistance against popular fiction also reflected concern for enlightenment and popular education. Efforts to teach the population to read were motivated by a desire to advance learning and maturity, whereas serial fiction was seen to encourage passive reading, romantic fantasizing and escapism. If people wanted to read, they should read something useful: geography, history and statistics, argued Swedish editor C.F. Bergstedt in an 1851 essay about "wretched literature"*. Serialized fiction caused young men to have "no energy for serious and beneficial work"* and young women to sacrifice "happiness, peace of conscience and progress for frivolity and entertainment”* (cited from Öhman 2002, 11).

First among those who resisted popular literature were the religious and literary establishments, with some support from the medical profession. But also to the relatively newer professions of teachers and librarians, resistance became an integrated element of organizational and professional ideology. "[T]he whole idea of fiction in the library was one which the profession wrestled with for many years," writes Bierbaum of US librarians (1994, 100). Librarians as a rule strongly denounced serial literature, and kept it out through the means available: selection lists, catalogues, including "not to be circulated" lists (Bierbaum 1994, 94). In schools, the main strategy was to "suppress it, pretend it does not exist, and in this way express their contempt"*, writes Tvinnereim about the early attitudes of Norwegian teachers $(1978,81)$.

The metaphors used about popular literature were inspired by the problems of the day, metaphors alluding to disease, garbage and sanitation flourished. Popular literature was likened to poison and pollution, epidemics, infestation, sewage, garbage, rottenness and thrash (see Lewis 2003, 145; Sutter 2003, 165; Öhman 2002, 9; Fang 2015, 48). The first urban sewage systems date back to the same time as serialized fiction, around 1840, and whereas uncontrolled sewage poisoned the body, literature was seen to poison the mind. 


\section{Cinema: Education for Crime}

Cinema shows began around 1900, and cinema rapidly became "the dominant institution in popular culture" (Black 1994, 6). Cinema transcended class, ethnic, gender and national differences, and soon became a controversial medium on both sides of the Atlantic. Movies were seen to rapidly intensify the process of demoralization; it drew young and vulnerable people out of their homes, tempted them into dark spaces and served them content of low quality and despicable moral standard (Grieveson 2004, 13, see also; Pearson 1984, 93; Drotner 1999, 605; Black 1994, 9). Young women were seen to be corrupted by movies romanticizing "illicit" love affairs and young men were incited to criminal behaviour by films "glorifying criminals" (Black 1994, 9). Instead of teaching the values and competences needed by the young and uneducated, they provided a different form of education; across national boundaries cinema was labelled "education for crime," "schools of vice and crime" (Black 1994, $10)$, a "training school of mischief, mockery, lawbreaking and crime" (Grieveson 2004, 15) and a "training ground for prostitution and robbery" (Thompson and Bordwell 2010, 29).

In response to the cinema's illusions of reality, new medical metaphors, involving psychiatry and mind control, became part of the vocabulary of resistance. Austrian psychiatrists Josef Breuer and Sigmund Freud had introduced hypnosis as a treatment for hysteria in the 1890s and hypnosis later became a metaphor for media effects. Cinema allegedly led to "surrender, under conditions of hypnotic receptivity, to the cheapest emotional appeals," wrote F. R. Leavis in 1930 (2006, 14). Compared to the cinema, popular fiction suddenly appeared more innocent, an argument spelled out by a Kansas philosophy professor:

$[\mathrm{P}]$ ictures are more degrading than the dime novel because they represent real flesh and blood characters and import moral lessons directly through the senses. The dime novel cannot lead the boy further than his limited imagination will allow, but the motion picture forces upon his view things that are new, they give firsthand experience (cited from Black 1994, 10).

This is one of many statements where genres that were widely condemned, appear more respectable because new genres are seen to be worse. Compared with popular fiction, the cinema was also seen to expose users to more serious health risks; risks of fire in unsafe buildings with 
inflammable nitrate films, concern that spitting in theatres would spread disease, unease over whether flickering lights would damage eyesight and induce epilepsy (Pearson 1984, 95; French and Petley 2007, 7). Familiar metaphors were used to describe cinema, such as dirt, filth and trash, but also new diagnoses were hinted at with metaphors such as "nickel delirium" (Black 1994, 6).

From around 1910, state and industry censorship boards emerged locally and nationally. In the US, local censorship boards were formed from 1908, and the industry allowed films to be censored to achieve respectability (Thompson and Bordwell 2010, 29). In Europe, virtually every country established some form of censorship, in Norway from 1913. In the UK, an act of law from 1909 required local authorities to issue licences to safe cinemas, but soon authorities also interfered with content. By 1912 the British Board of film Censors was established, becoming the accepted selfgovernance board from 1913 (Robertson 1989, 1).

For those who resisted cinema's presence and potential influence, pushing for political and institutional control was an obvious choice. Books and print had been subject to censorship, and when cinema emerged in the early 1900s, the police already had both in Europe and the US authority to withdraw licences from music halls, variety shows and other public spectacles if performers included offensive material (Mathews 1994; Nymo 2002, 20).

The campaigns to censor cinema were coalitions, with some types of professions and social activists involved across national borders. Churches and clergy of different denominations organized protests and boycotts of films judged immoral by church authorities (Black 1994, 2). Churches were joined by social reform movements for juvenile protection, virtuous lifestyles and temperance. In the US, the Progressive reform movement fought corruption, child labour, unsafe houses and factories, prostitution and alcoholism, but also "immoral" media - from books and newspapers to cinema (Black 1994,8$)$. Nymo $(2002,22)$ points to the activism of teachers as instrumental to achieve Norwegian cinema censorship; the teachers' seminars and the enlightenment ethos laid the foundation for a professional self-confidence and status that teachers could draw on in their struggle to restrict popular culture.

Many women and women's groups were active campaigners (Evensmo 1992, 61; Black 1994, 9; Nymo 2002, ch. 2). Middle class ideals presumed that women were virtuous and should act as moral guardians, and female reformers became a counterpart to masculine pursuits such as 
drinking alcohol and using prostitutes (Grieveson 2004, 27, 29). Censorship is often seen as a class issue (Mathews 1994, 1), yet campaigns drew support from across the political spectrum, also from labour representatives who saw the movie industry as "capitalist" and "speculative" (Nymo 2002, 35).

\section{Radio: Risk of Contagion}

Early radio was blamed for a lot of things: "dizzy spells, changes in weather, creaky floorboards," Barnouw writes $(1966,103)$ and cites the example of a farmer complaining to a Louisville station that radio waves had killed a blackbird and potentially might kill him. In general, however, radio was met with the kind of enthusiasm that would later greet the Internet (Ch. 5); a discourse that "glorified radio's special properties" to unify disparate communities and build a national culture (Hilmes $1997,1)$. But as radio became a mass medium, radio was subject to similar warnings and scepticism as other mass media, in particular concern that radio would undermine cultural standards, and be used as a tool to threaten democracy.

Radio was first used for ship-to-shore communication in the early 1900s, but was soon embraced by enthusiastic amateurs (Briggs 1985; Dahl 1975; Barnouw 1966). With the outbreak of World War I in 1914, amateur activity was suspended, and the initiative passed to the armed forces (Dahl 1975; Hilmes 2007; Briggs 1985). David Hendy, who has studied the development of wireless on the eve of World War I, describes an atmosphere of "control, paranoia and anxiety" $(2013,77)$. An important metaphor to describe the negative effect of radio was that of contagion; "the fear that wireless could spread information - or more precisely misinformation - in an uncontrolled way." Wireless was invisible, synchronous, and messages could be heard by anybody. "It was increasingly clear that, given the special qualities of wireless, it needed to stay in the 'right' hands" (81).

But whose hands were right? After the war, controversy erupted in many countries over how radio should be controlled, involving state actors as well as social and cultural movements, manufacturers and advertisers, and educational institutions. The different paths taken had important implications for the development of broadcasting, and also for the evolvement of media resistance.

In the US, radio proliferated with a multitude of operators, many of which were universities and educational establishments. But "apathy," 
"disgust" and "weariness" set in (Barnouw 1966, 173) as interference led to "chaos." Proponents of educational and public service lost out as the 1927 Radio Act turned radio into a commercial medium run by networks, although more regulated than press and movies (Hilmes 2007, 44). In Europe, in contrast, private companies operating on a licence were replaced by state monopolies. The British Broadcasting Corporation (BBC) was established in 1927 in an atmosphere of "choice between monopoly and confusion" (Briggs 1985, 33); its mandate to provide national broadcasting with "no concessions to the vulgar" (55). In his Broadcast over Britain, the first Director-General of the BBC John Reith refused to accept that radio should give people "what they want." Few know what they want, and very few what they need, Reith proclaimed, and said that "our responsibility is to carry into the greatest possible number of homes everything that is best in every human department of knowledge, endeavour and achievement, and to avoid the things which are, or may be hurtful" (Reith 1924, 34).

In the US, where radio developed commercially, criticism erupted over moral standards. In a more profound way that other media, radio transcended boundaries of age, class, gender and geography, as well as between public and private spaces. The base in advertising was seen to draw radio towards "the vulgar, the barbaric and the illegitimate" (Hilmes 2007, 55). Of particular concern was jazz music, which, like many other forms of popular culture, was seen as "degrading" and "lowers all the moral standards"; according to protesters jazz left the listeners "incapable of distinguishing between good and evil, between right and wrong" (cited from Hilmes 1997, 48). In Europe, the BBC attempted to "root out" American influence and preserve a greater distance from the audience; the style was different from the friendly, informal and democratic style of American radio (Scannell and Cardiff 1991, 293). Yet, British radio was also criticized for undermining morality and culture. Wolfe (1984) notes that churches were sometimes positive, but "more often cautious and belligerently negative" to radio, believing it to "threaten clerical and ecclesial autonomy" (xxii, see also Brigg 1965, part II). British literary critic F. R. Leavis in 1930 expressed concern about passive listening and saw radio to have a standardizing influence that "hardly admits of doubt" $(2006,14)$.

Perhaps the strongest concern surrounding radio was that it could aid threats to democracy. During World War I, the media were used, for the first time, in a large-scale effort to control and manipulate public opinion (Ward 1989, 58). From the time the Nazi Government took power in 
Germany in the 1930s, the threat became even more direct, as radio, film and public loudspeakers were used to rally support and mobilize the masses (113). Members of the Frankfurt school, who had sought refuge in the US to escape Nazi persecution in Germany, were dismayed by the use of media for propaganda. However, Horkheimer and Adorno saw no guarantee in the US commercial radio model:

In America it collects no fees from the public, and so has acquired the illusory form of disinterested, unbiased authority which suits Fascism admirably. $(1997,159)$

The debate over radio prompted new stark metaphors, such as "contagion," but also "chaos in the ether" and "the tower of babel" (e.g. Barnouw 1966). The biblical legend of the Tower of Babel - where different languages are God's punishment to Man - symbolized human curiosity and desire, but also arrogance leading to chaos and confusion. Radio was seen as having great potential for good, but in the war-torn first half of the twentieth century, it was also seen as a potential means of destruction.

\section{Comics: Horror and Mutilations}

The sale of comic books exploded in the late 1940s and early 1950s, during and in the direct aftermath of World War II. While many of the comics were innocent enough, with themes familiar from popular culture, others broke new ground in terms of sex, violence and horror. The resistance against comic books marks a shift to an era where traditional values confront a more liberal cultural climate (Gilbert 1986, 13-14). Comics were part of the wartime and post-war boom in popular culture, but the short distance to the atrocities of war also led to astonishment and disbelief as to the level of violence and brutality.

Again, the content was argued to be more amoral, and generally worse, than that of previous media. In addition to horror and violence; protest erupted over the portrayal of sexually active and powerful women, evil children, and what critics saw as role models for homosexuality (in Batman and Robin and Wonderwoman) (Wertham 2004; first publ. 1954, 190192, 234, see also; Lepore 2014). Until the comic book era, alleged the influential US psychiatrist and anti-comics campaigner Frederic Wertham, "there were hardly any serious crimes such as murder by children under twelve" $(2004,155)$. Now, however, there were evidence of "a significant 
correlation between crime comics reading and the more serious forms of juvenile delinquency" (164).

Fredric Wertham was an important force in the anti-comics' campaign. From 1948, he wrote critical pieces in magazines such as The Ladies Home Journal and Readers Digest (Bastiansen and Dahl 2003, 344). Seduction of the Innocent, his 1954 book, had "enormous influence" both in the US and Europe (Barker 1984a, 56-57). Reibman (2004, xi) characterizes Wertham as "a traditional left-wing European intellectual and product of the Enlightenment tradition"; as a first generation Jewish immigrant from Germany in the 1920s he finds it ironic that Wertham should be characterized as a "reactionary." Yet, Wertham's ferocious critique of comic books is yet another illustration that resistance to media and genres have come both from left and right.

In later decades, Wertham has been criticized for both misrepresenting content (Barker 1984a) and fabricating evidence from clinical trials (Johnston 2013). Wertham himself, however, was frustrated that he did not get more support from science and academia. After a description of "Jungle comics" which "specialise in torture, bloodshed and lust in an exotic setting" he sighs:

Whenever I see a book like this in the hands of a little seven-year-old boy, his eyes glued to the printed page, I feel like a fool to have to prove that this kind of thing is not good mental nourishment for children! What is wrong with the prevailing ethics of educators and psychologists that they have silently permitted this kind of thing year after year...? (31)

Wertham's comment reflects exasperation that experts were not unanimous; indeed, the debate about comics reflects disappointment over the early studies of media effects. In a 1954 Norwegian parliamentary debate about comics, there are references to Wertham's argument, but also to experts disputing the copycat effect (516). It is lamented that no unanimous scientific conclusions have been reached despite this being an issue which scientists wrestle with all over the world $(1954,509,510$, see also Lepore 2014). For some members of the Norwegian Parliament, however, the level of violence was indication enough that something had to be done. As one member, Erling Wikborg, argued (St.tid 1954, 508),

Many of these series - and this is serious - undermines respect for human dignity. They often degrade women. Sometimes other races are degraded. 
The series are filled with all dreadful possibilities in terms of brutality, torture, murder and many kinds of crimes. Some series even depicts crippled, deformed and coloured people as especially criminal.*

Great sacrifices had been made during the war to protect civilized life, democracy and enlightenment, and now comics laden with misogyny, Nazism, racism and negative stereotyping became popular entertainment.

Campaigns against comics erupted simultaneously in many countries and led to legislation or self-regulation (Bastiansen and Dahl 2003, 346). In the US, Wertham campaigned for a law against the sale of violent comics to children under fifteen, and public hearings and legal action followed (Gilbert 1986, 106). While a self-censorship Comics code was adopted in the US in 1954, "labelling the suitability of each comic book now published" (Reibman 2004, xxvii), so-called horror comics were outlawed in Britain in 1955 (Barker 1984a, 5).

Allies in the struggle against comics were teachers, scientists, librarians, psychologists, doctors and police. In Britain, the arguments against comic books resonated with religious, educational and political interests, including Communist Party members who were concerned about Americanization and the corruption of the young (Barker 1984a, 29). In a parallel to the campaign for cinema censorship (above), Barker points to the National Union of Teachers as a decisive force in the campaign against British horror comics (1984a, 15). The educational and literary professions were particularly incensed by the industry's attempt to achieve respectability for popular culture through the use of high culture. Already Shakespeare plays had been adopted for the cinema (Thompson and Bordwell 2010, 29-30) and now they were put into comic strips: "Shakespeare and the child are corrupted at the same time" is Wertham's verdict on the marketing of comic-book Macbeth with the slogan "a dark tragedy of jealousy, intrigue and violence adapted for easy and enjoyable reading" (143, see also MacDonald 2011).

Publishers claimed that comics were good for children, teaching them to read; trying to capitalize on the higher legitimacy of print compared with image-based media. But the protesters did not buy it. According to Wertham, comics prevented children from developing the necessary leftto-right eye movements (127), prompted the habit of gazing rather than reading (139), destroyed the taste for good books (140), made children bad spellers (144), and taught words which were not proper words, such as ARGHH, WHAM, THUNK, YEOW, BLAM (145). 
Although some restrictions were initiated, campaigners were not content; there was a sense that the legal path was becoming more difficult to pursue, and support for censorship was vanishing. In Norway, Wikborg expressed disappointment that authorities did not recognize that comics were downright criminal (St.tid 1954, 518):

If prosecutors would monitor these comics with greater attention, they would find more than one opportunity to use the provisions of the Criminal Code. I am thinking of para 140 of incitement to crime, para 142 about blasphemy, para 160 which speaks of public instruction in the use of explosives to commit crimes. We also have paragraphs 322 and 323 of criminal content in printed publications. We already have a number of provisions that can be used, but I have the impression that the prosecution has been rather hesitant when it comes to these issues. *

Wikborg, a lawyer as well as a parliamentary representative for the Christian People's Party would continue to oppose new media; four years later he would deem television to be "exceedingly dangerous" * (St.tid. 1957, 2458-2459) and he also believed the Norwegian radio corporation to have "skeletons in their closets"* (St.tid 1954, 509).

Reactions against comics stimulated new metaphors, which were both sexual and violent. Norwegian author Bjørn Rongen saw comics as "spiritual rape of minors"*, whereas a Danish author Tørk Haxthausen pigeonholed them as "education for terror"* in 1954 (Bastiansen and Dahl 2003, 345). Comics induced depravity and destroyed human souls, hence, the title of Wertham's book "Seduction of the Innocent" and metaphors used by him such as an "orgy of brutality" (111).

\section{What IS AT STAKE?}

The preoccupations of media resistance are not some peripheral concerns; they are connected with broader cultural, social and political struggles at the time. As noted in the introduction, six recurring values have been identified in media resistance from the early mass media era; new media were seen to undermine morality, culture, enlightenment, democracy, community and health.

In the early phases of resistance the most prevalent values that the media were seen to undermine was morality and culture. Media and cultural depictions were conceived as vehicles to raise standards, both 
morally and in terms of taste and quality, and resistance reflected disappointment when these expectations were not met. The emergence of the first mass media coincided with the height of Victorian morality; the prominence of the British Empire ensured that Victorian values spread across the world and shaped the ideals of the new middle classes (Sundin and Willner 2007, 141; Black 1994, 21-22). Central to Victorian morality was that the upper classes should inspire and raise the standards of the lower class; Victorian authors produced stories of poor children and families following the path of virtue (Fang 2015, 75), whereas new media "delighted in ridiculing 'Victorian values" (Black 1994, 7).

What critics saw as vulgarity and depravity intensified with each new medium, and so did also the conviction that culture was at stake. "It is commonplace today that culture is in crisis," stated British literary critic F. R. Leavis in the 1930 pamphlet Mass Civilization and Minority Culture $(2006,13)$. Leavis saw the emerging media as contributing to "a process of levelling-down" leading to passive consumption and loss of taste:

Broadcasting, like the films, is in practice mainly a means of passive diversion ... it tends to make active recreation, especially active use of the mind, more difficult (14).

Leavis represents a position where high culture and cultural aspirations are seen as the basis for civilized life. Culture represents man's best achievements and high morality, whereas the mass media represented low culture and amorality (Storey 2009). Although the perspective has lost ground, Storey considers the approach "foundational," still representing the "common sense" approach in some circles (33). From the left, the mass media were seen as agents of standardization and uniformity, destroying aristocratic high culture as well as authentic folk culture. Under the prevailing conditions, argued Horkheimer and Adorno (1997; first publ. 1944), "all mass culture is identical" (121) and "broadcast programs are all exactly the same" (122). Instead of contributing to enlightenment and social consciousness, popular media destroyed the masses by drowning them in pleasure (143).

Those who protest against media are often conceptualized as reactionary or backward; and much media resistance in the early phases hark back to a nostalgic past. But arguments and positions also point in other directions. On the one hand, there is criticism that media are destroying what is dear and valuable, on the other hand, there are arguments that the media stand in the 
way of progress. These latter arguments reflect not only disappointment that media depicted bad rather than good behaviour, but also disappointment that the emerging media did not, to a stronger degree lend themselves to progressive causes such as educational enlightenment and improvement of public health. Progressive campaigners on both sides of the Atlantic were disappointed with the escapist public, and media that prioritized triviality, superstition and frivolous entertainment. In the long run, it was argued, this would hamper the development of mature and competent citizens, and prevent youngster from developing into competent and healthy adults.

From the eighteenth century, authorities visibly increased their public health ambitions and a steep decline in mortality followed, but the industrial revolution brought new health risks, such as pollution and epidemics (Sundin and Willner 2007). Many saw the emerging media as part of the new risks, not only were there concern for eyesight, brain damage, mental distortion and "psychic infections" (cited from Grieveson 2004, 12), there were also concerns that spectators would burn to death or catch infections in dilapidated cinema theatres.

The debate over early mass media reflected the concerns over mass society; concepts such as "mass culture," "mass art," "mass entertainment" and "mass media" were all coined in the interwar period. The problem of the masses was a common theme in social thought, whether Marxist, Christian or liberal (Bastiansen and Dahl 2003, 237-238). On the one hand there was concern that the masses were inherently amoral and destructive, in the words of Spanish mass society theorist José Ortega y Gasset: "The mass crushes beneath it everything that is different, everything that is excellent, individual, qualified and select" (1993, first publ. 1930, 18). On the other, there were concern about authoritarian states indoctrinating the masses with the use of media propaganda, a concern reinforced by the rise of totalitarianism in Italy, Germany and the Soviet Union.

The concern with mass society is also relevant for the argument that mass media would undermine community. Media and communication technology is often depicted as bringing people together, but to sceptics and critics media brought isolation. As Fang puts it $(2015,4)$,

For the many centuries during which most of the world was illiterate, people received their information from each other, from travelers and from their local priests. Entertainment came from one another in the form of singing, dancing and story-telling. The shared element was community. Each other. Media brought isolation. 
According to mass society theorists, uniformity and conformity characterized modern societies, eroding traditional bonds and communal solidarity. In the US, the Progressive reform movement worked to reform urban America by returning to values of local communities (Geraghty 2009, 4). The philosopher John Dewey was a major progressive theorist, who shared the concern that industrial society and mass media were destroying the communal basis of society (Dewey 1991; first publ 1927; see also Hilmes 2007,18 ). Dewey describes a situation where, in the 1920s, there were already too much media - the telegraph, telephone, radio, mail and printing press. He argued that "the physical and external means of collecting information... have far outrun the intellectual phase of inquiry and organization of the result" (1991, 180).

The six concerns - for morality, culture, enlightenment, democracy, community and health - are not mutually exclusive; they are linked and overlap, but also illustrate that media resistance may emerge from different, and often contradictory positions. In addition to concerns about different values, there were resistance to different aspect of the media: technology, structure, content and functions. Resistance evolves in response to each new medium and mode shift: From oral to written communication, from writing to print, from print to images, from oral to radio, from photographs to movies. It is interesting to observe how protesters often contrast the functions of a new medium with a medium already an object of resistance; while this may alert sceptics to new dangers, the effect would also have been to make existing media appear more innocent, thus aiding the process of media acceptance.

\section{What TO Do?}

For resistance to be manifest it is not sufficient that someone is concerned; organizations, politicians, professionals or other actors must also act publicly, suggest measures and organize protest (Phillips 2008). But what could those who resisted new media really do? Herbert Stone wanted to "smash the Vitascope" and the Church in early modern Europe destined objectionable books to public bonfires. As we get closer to own time, suggestions that media be destroyed or banned become less frequent. In the early era of the mass media, in the nineteenth and twentieth centuries, protestors largely fought for legal, political and institutional control and censorship. Cinema was censored from around 1910; the outbreak of World War I led to state takeover of radio, in the 1920s radio became 
regulated as public companies in Europe, in the 1940s and 1950s anticomics campaigners succeeded in instigating prohibition and censorship.

In order for censorship and control to function, professions and experts must exercise discretion and authority. Churches, schools and libraries were important gatekeepers for keeping out undesirable printed material. With popular literature, as well as movies and comics, panels of experts were set up to vet, evaluate and recommend. Educational, religious and medical professions were also influential in advisory bodies for early broadcasting. State and public broadcasting institutions, as well as the US radio networks and their self-regulatory mechanisms, are prominent examples of institutional control of media.

In the cases I have discussed from early mass media history, I have not seen material where consumers pledge abstinence because they were convinced that media were bad for them. But there are plenty of efforts to convince others to abstain from media. A whole range of social and political movements was active in the struggle against early popular media and genres. Campaigners used parents' meeting to mobilize support and urged parents to behave responsibly and restrict youngsters' media consumption. Appeals were directed at producers and distributors to behave responsibly. For example, in a 1954 parliamentary debate on comics in Norway, a representative suggested an information campaign to "get newsagents and tobacconists to refuse to sell this filth"* (St.tid 1954, 515).

Resistance travels across borders and protesters, such as Fredric Wertham, helped to inspire campaigns in many countries. There are also references to the involvement of international bodies, in the case of comics, critics refer to debates in UNESCO, a United Nations agency established in 1945 that would later develop a strong media-critical agenda (St.tid 1954, 507-508). Studies show that the methods used were similar from one campaign to the next (see for example Grieveson (2004) on the US and Nymo (2002) on the Norwegian cinema campaigns, and Barker (1984a) on the UK comics campaign). The campaigners' toolkit was similar to that of any social or political activist of the twentieth century: public meetings were held, petitions were directed at politicians, pamphlets produced, lists of speakers were offered to conferences, letters were written to the press, alliances built with experts and professional bodies. A method that was often used in this early period was to collect particularly despicable pieces of content to show to legal authorities, politicians, clergy and press in order to create a public outcry. Likewise, campaigners collected 
examples of stories indicating potential copycat behaviour. As one British anti-comic campaigner described the situation in retrospect,

We looked - it is almost wicked to say this - with eager anticipation for a story in the press of a child who had done something so that we could point to the comics. And if one had done something, then this supported our case. And we called this research. (Joe Benjamin, anti-comics campaigner, cited in Barker 1984a, 182)

The quote illustrates how protesters did "research" and how many yearned for scientific evidence and proof of media's detrimental character. Systematic media research was of course initiated; such as the 1928 Payne Fund study on cinema effects and the Office of Radio Research with Paul Lazarsfeld and colleagues at Columbia University from the 1930s (Ytreberg 2008, 40). But as the period of early mass media resistance came to an end, there was reason to be disappointed, as expert evidence became increasingly contradictory. Those critical and sceptical of the way media transformed society would not get an unambiguous answer from science, but there were other sources of inspiration: not least engaging and popular fiction stories where bad media played a part in undermining civilization and leading to apocalypse.

Open Access This chapter is licensed under the terms of the Creative Commons Attribution 4.0 International License (http://creativecommons.org/licenses/ by $/ 4.0 /$ ), which permits use, sharing, adaptation, distribution and reproduction in any medium or format, as long as you give appropriate credit to the original author(s) and the source, provide a link to the Creative Commons license and indicate if changes were made.

The images or other third party material in this chapter are included in the book's Creative Commons license, unless indicated otherwise in a credit line to the material. If material is not included in the book's Creative Commons license and your intended use is not permitted by statutory regulation or exceeds the permitted use, you will need to obtain permission directly from the copyright holder.

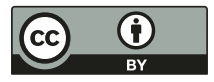

